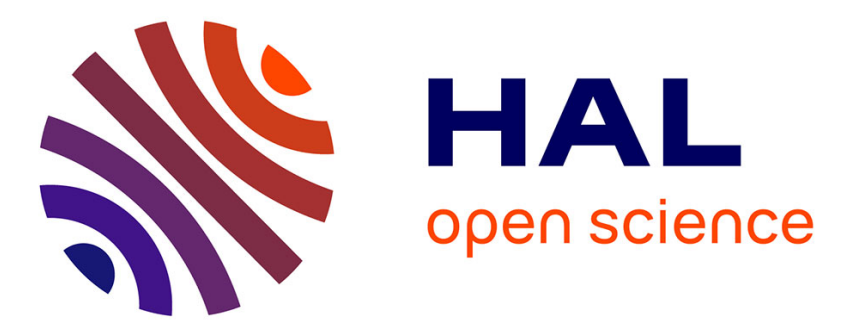

\title{
Linkage disequilibrium between the allele and wildtype and alleles: identification of haplotypes in healthy Nordic populations
}

\author{
Rasmus S. Pedersen, Charlotte Brasch-Andersen, Sarah C. Sim, Troels K. \\ Bergmann, Jónrit Halling, Maria S. Petersen, Pál Weihe, Hege Edvardsen, \\ Vessela N. Kristensen, Kim Brøsen, et al.
}

\section{To cite this version:}

Rasmus S. Pedersen, Charlotte Brasch-Andersen, Sarah C. Sim, Troels K. Bergmann, Jónrit Halling, et al.. Linkage disequilibrium between the allele and wildtype and alleles: identification of haplotypes in healthy Nordic populations. European Journal of Clinical Pharmacology, 2010, 66 (12), pp.1199-1205. 10.1007/s00228-010-0864-8 . hal-00612005

\section{HAL Id: hal-00612005 https://hal.science/hal-00612005}

Submitted on 28 Jul 2011

HAL is a multi-disciplinary open access archive for the deposit and dissemination of scientific research documents, whether they are published or not. The documents may come from teaching and research institutions in France or abroad, or from public or private research centers.
L'archive ouverte pluridisciplinaire HAL, est destinée au dépôt et à la diffusion de documents scientifiques de niveau recherche, publiés ou non, émanant des établissements d'enseignement et de recherche français ou étrangers, des laboratoires publics ou privés. 


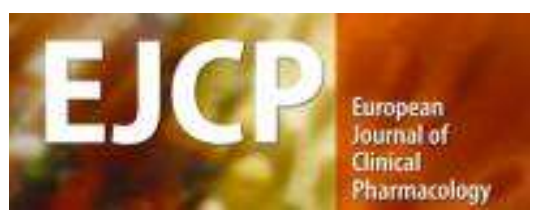

\section{Linkage disequilibrium between the rapid CYP2C19*17 allele and wildtype CYP2C8 and CYP2C9 alleles: Identification of CYP2C haplotypes in healthy Nordic populations}

\begin{tabular}{|c|c|}
\hline Journal: & European Journal of Clinical Pharmacology \\
\hline Manuscript ID: & EJCP-2010-0210.R1 \\
\hline Type of submission: & Original \\
\hline $\begin{array}{r}\text { Date Submitted by the } \\
\text { Author: }\end{array}$ & 01-Jul-2010 \\
\hline Complete List of Authors: & $\begin{array}{l}\text { Pedersen, Rasmus; University of Southern Denmark, Clinical } \\
\text { Pharmacology } \\
\text { Brasch-Andersen, Charlotte; University of Southern Denmark, } \\
\text { Clinical Pharmacology } \\
\text { Sim, Sarah; Karolinska Institutet, Section of Pharmacogenetics, } \\
\text { Department of Pharmacology and Physiology } \\
\text { Bergmann, Troels; University of Southern Denmark, Clinical } \\
\text { Pharmacology } \\
\text { Halling, Jónrit; The Faroese Hospital System, Department of } \\
\text { Occupational Medicines and Public Health } \\
\text { Petersen, Maria; The Faroese Hospital System, Department of } \\
\text { Occupational Medicines and Public Health } \\
\text { Weihe, Pál; The Faroese Hospital System, Department of } \\
\text { Occupational Medicines and Public Health } \\
\text { Edvardsen, Hege; Oslo University Hospital, Radiumhospitalet, } \\
\text { Department of Genetics } \\
\text { Kristensen, Vessela; Oslo University Hospital, Radiumhospitalet, } \\
\text { Department of Genetics } \\
\text { Brosen, Kim; University of Southern Denmark, Clinical } \\
\text { Pharmacology } \\
\text { Ingelman-Sundberg, Magnus; Karolinska Institutet, Section of } \\
\text { Pharmacogenetics, Department of Pharmacology and Physiology }\end{array}$ \\
\hline
\end{tabular}

\section{S) ScholaroNE




\section{Linkage disequilibrium between the $C Y P 2 C 19 * 17$ allele and type CYP2C8 and CYP2C9 alleles: Identification of CYP2C haplotypes in healthy Nordic populations}

Rasmus S. Pedersen ${ }^{1,2}$, Charlotte Brasch-Andersen ${ }^{1}$ Sarah C. Sim ${ }^{2}$, Troels

K. Bergmann ${ }^{1}$, Jónrit Halling ${ }^{1,3}$, Maria S. Petersen ${ }^{1,3}$, Pál Weihe ${ }^{3}$, Hege

Edvardsen $^{4,5}$, Vessela N. Kristensen ${ }^{4,5,6}$, Kim Brøsen ${ }^{1}$ and Magnus

Ingelman-Sundberg ${ }^{2}$

${ }^{1}$ Institute of Public Health, Clinical Pharmacology, University of Southern Denmark,

Odense, Denmark

${ }^{2}$ Section of Pharmacogenetics, Department of Physiology and Pharmacology,

Karolinska Institutet, Stockholm, Sweden

${ }^{3}$ Department of Occupational Medicines and Public Health, The Faroese Hospital

System, Tòrshavn, Faroe Islands

${ }^{4}$ Department of Genetics, Institute of Cancer Research, Oslo University Hospital

Radiumhospitalet, Oslo, Norway

${ }^{5}$ Institute of Clinical Medicine, University of Oslo, Oslo, Norway

${ }^{6}$ EpiGen, Institute for Clinical Medicine, Akershus University Hospital, Oslo, Norway

Correspondence:

Rasmus Steen Pedersen, Institute of Public Health, Clinical Pharmacology, University of Southern Denmark, Odense, Denmark. E-mail: rpedersen@health.sdu.dk. Phone:

+45 65503305. Fax: +45 65916089 


\begin{abstract}
Purpose. To determine the distribution of clinically important CYP2C genotypes and allele frequencies in healthy Nordic populations with special focus on linkage disequilibrium.

Methods. 896 healthy subjects from three Nordic populations (Faroese, Danish and Norwegian) were genotyped for five frequent and clinically important $C Y P 2 C$ allelic variants: the defective $C Y P 2 C 8 * 3, C Y P 2 C 9 * 2, C Y P 2 C 9 * 3$ and $C Y P 2 C 19 * 2$ alleles, and the $C Y P 2 C 19 * 17$ allele that causes rapid drug metabolism. Linkage disequilibrium was evaluated and $C Y P 2 C$ haplotypes were inferred in the entire population.

Results. Ten CYP2C haplotypes were inferred of which the most frequent (49\%) was the $C Y P 2 C$ wildtype haplotype carrying $C Y P 2 C 8^{*} 1, C Y P 2 C 9 * 1$ and $C Y P 2 C 19^{*} 1$. The second most frequent haplotype (19\%) is composed by $C Y P 2 C 19 * 17, C Y P 2 C 8 * 1$ and $C Y P 2 C 9 * 1$. This predicted haplotype accounts for $99.7 \%$ of the $C Y P 2 C 19 * 17$ alleles found in the 896 subjects.

Conclusion. CYP2C19*17 is a frequent genetic variant in Nordic populations that exists in strong linkage disequilibrium with wild type $C Y P 2 C 8^{*} 1$ and $C Y P 2 C 9 * 1$ alleles, which effectively makes it a determinant for a haplotype exhibiting efficient CYP2C substrate metabolism.
\end{abstract}




\section{Introduction}

Human cytochrome P450 2C (CYP2C) enzymes are responsible for the metabolism of approximately $25 \%$ of clinically used drugs [1] and some endogenous substances such as arachidonic acid [2]. The human CYP2C subfamily includes CYP2C8, CYP2C9, CYP2C18 and CYP2C19 that are homologous and share more than $80 \%$ amino acid sequence identity [3]. However, only CYP2C8, CYP2C9 and CYP2C19 are considered of clinical importance [4], since CYP2C18 mRNA is detected at relatively low amounts [5]. The entire CYP2C gene locus spans approximately $500 \mathrm{~kb}$ on chromosome 10 with the gene order Cen-2C18-2C19-2C9-2C8-Tel (Figure 1) and each of the genes consist of nine exons with conserved exon/intron boundaries [6]. CYP2C8, CYP2C9 and CYP2C19 exhibit clinically important genetic polymorphism as a result of single nucleotide polymorphisms (SNPs) (www.cypalleles.ki.se).

CYP2C8 catalyzes the metabolism of several clinically used drugs such as the anti-cancer drug paclitaxel, the anti-arrhythmic drug amiodarone, the antidiabetic drug repaglinide, and the thiazolidinediones rosiglitazone and troglitazone [7]. Fourteen all ariants of CYP2C8 have been described of which some cause poor metabolism [8]. CYP2C8*3 is a quantitatively and functionally relevant variant allele in the Caucasian population with a reported frequency of $10-23 \%$ but rare or absent in Asian and African populations [5]. CYP $2 C 8^{*} 3$ is defined by two amino acid substitutions in exon 3 and exon 8 (Table 1), respectively, causing decreased paclitaxel turnover [9] and decreased paclitaxel clearance in vivo [10].

CYP2C9 is among the most important drug metabolizing enzymes in humans. It is involved in the metabolism of several important drugs including phenytoin, losartan, $(S)$-warfarin, tolbutamide and numerous NSAIDs [11]. Of the 34 allelic variants that have been described [12], the two clinically most important variant alleles are $C Y P 2 C 9 * 2$ and $C Y P 2 C 9 * 3$, which both cause a defective CYP2C9 enzyme (Table 1)[13]. The allele frequencies of $C Y P 2 C 9 * 2$ and $C Y P 2 C 9 * 3$ are approximately $10-15 \%$ and 5-10\%, respectively, in European populations [14].

CYP2C19 is another important drug metabolizing enzyme encoded by a highly polymorphic gene [15]. The racemic anticonvulsant drug mephenytoin is the classic probe drug where the 4-hydroxylation of the $(S)$-enantiomer is catalysed by CYP2C19. Furthermore, a range of clinically important drugs including diazepam, 
omeprazole and other proton pump inhibitors, the antidepressants citalopram, escitalopram and imipramine, the antimalarial drugs proguanil and chlorproguanil, the $\beta$-adrenoceptor blocker propranolol, and the antiplatelet drug clopidogrel are metabolized or bioactivated by CYP2C19. Population studies have shown that individuals that are homozygous for the inactivating allele $C Y P 2 C 19 * 2$ that leads to a splicing defect (Table 1), are phenotypic poor metabolizers of CYP2C19 substrates $[5,16,17]$. The CYP2C19 poor metabolizers only represent $3-5 \%$ of Caucasian populations, but is found in $12-23 \%$ of Asian populations [3]. In recent years, much attention has focused on the allele $C Y P 2 C 19 * 17$ that correlates with high in vivo CYP2C19 activity and is present at an allele frequency of $18 \%$ in a Swedish healthy population [18]. The initial finding of a rapid drug metabolism phenotype was later supported by a clear association of lower plasma concentration of omeprazole and escitalopram in subjects homozygous for CYP2C19*17 [19,20]. Interestingly, CYP $2 C 19 * 17$ also leads to increased bioactivation of the antiplatelet drug clopidogrel that causes an almost 4-fold higher risk of bleeding complications in CYP $2 C 19 * 17$ homozygotes, but no beneficial antithrombotic effect for patients undergoing percutaneous coronary intervention [21]. As opposed to subjects homozygous for the CYP2C19*1 allele, subjects homozygous for $C Y P 2 C 19 * 17$ display a very low interindividual variation in CYP2C19 metabolism [19,22]. The rapid phenotype caused by $C Y P 2 C 19 * 17$ has been explained by a recruitment of transcription factor(s) by the $-806 \mathrm{C}>\mathrm{T}$ conversion (Table 1) in the gene promotor region that causes an increased transcriptional rate [18]. A hypothesis is that $C Y P 2 C 19 * 17$ is also a haplotype marker within the CYP2C locus [19]. In fact, haplotype block structures at the $C Y P 2 C$ locus have been described [23,24]. Almost all subjects carrying $C Y P 2 C 8 * 3$ also carry $C Y P 2 C 9 * 2$ and three quarters of all subjects carrying $C Y P 2 C 9 * 2$ also carry $C Y P 2 C 8 * 3$ [25]. CYP2C19*2 and $C Y P 2 C 19 * 3$ has also been shown to be linked with CYP2C18 mutations in Japanese subjects [26].

The aim of this study was to determine important $C Y P 2 C$ genotypes with special focus on $C Y P 2 C 19 * 17$ in healthy Nordic populations, and to investigate the linkage disequilibrium between them.

\section{Methods}


Samples

DNA samples from 276 healthy volunteers living around Odense in Denmark and previously genotyped for $C Y P 2 C 9 * 2$ and $C Y P 2 C 9 * 3$ [14], and 311 Faroese samples from healthy volunteers previously genotyped for $C Y P 2 C 8 * 3, C Y P 2 C 9 * 2$, CYP2C9*3 and CYP2C19*2 [27] were included in this study. Furthermore, DNA samples from 328 Norwegian Caucasian blood donors that had not been genotyped for $C Y P 2 C$ variants were included $[28,29]$.

Genotyping

A total of 915 DNA samples from three different populations were available for genotyping and the aim was to cover the five clinically important $C Y P 2 C$ allelic variants; CYP2C $8 *, C Y P 2 C 9 * 2, C Y P 2 C 9 * 3, C Y P 2 C 19 * 2$ and $C Y P 2 C 19 * 17$. All 276 DNA samples from Denmark [14] were successfully genotyped for $C Y P 2 C 8 * 3$, CYP $2 C 19 * 2$ and $C Y P 2 C 19 * 17$ and all the 311 Faroese samples were successfully genotyped for $C Y P 2 C 19 * 17$. Of the 328 Norwegian DNA samples, 309 were successfully genotyped for all five $C Y P 2 C$ variants. The analyses were performed using Applied Biosystems TaqMan ${ }^{\circledR}$ SNP genotyping assays (Table 1) according to the guidelines and conducted on an Applied Biosystems StepOne Plus apparatus or an Applied Biosystems 7500 Real Time PCR apparatus.

Sta Possible deviation from Hardy Weinberg equilibrium was tested for each SNP with Pearsons Chi-Square test with a level of significance of 5\%. Overall differences of allele frequencies between the populations were also tested by Chi-Squared test with a level of significance of 5\%. "Head to head" comparison between the populations was tested with Fisher's exact test with a level of significance of 5\%.

\section{Linkage disequilibrium and haplotype inference}

The software Haploview was used to visualize the structure of pair-wise linkage disequilibrium (LD) between the SNPs (in terms of Lewontin's D') [30]. Individual haplotypes were inferred by use of the five CYP2C SNPs and software package PHASE version 2.1 [31,32]. This software infers haplotypes from population genotype data using a Bayesian statistical method. We performed PHASE analyses 
with default settings ten times with different random seed. Additionally, haplotype frequencies were estimated using the expectation maximation algorithm (EM) in STATA10 (StataCorp, Texas, USA).

\section{Results}

We performed genotyping of $C Y P 2 C 8 * 3, C Y P 2 C 9 * 2, C Y P 2 C 9 * 3, C Y P 2 C 19 * 2$ and $C Y P 2 C 19 * 17$ in three different Nordic populations. The genotype and allele frequencies in the Danish, Faroese and Norwegian samples are presented in Table 2. All SNPs in all three populations were in Hardy-Weinberg equilibrium displaying $\chi^{2}$ values less than 3.84 .

An overall significant difference in allele frequency of CYP2C19*17 was found between the populations ( $\mathrm{P}=0.010)$. The allele frequency of $15 \%$ in the Faroese population ( $\mathrm{n}=311)$ was lower than the $20 \%$ in the Danish population $(\mathrm{n}=276)$ $(\mathrm{P}=0.038)$ and the $22 \%$ in the Norwegian population $(\mathrm{n}=309, \mathrm{P}=0.003)$. No statistically significant difference between the Danish and the Norwegian population was found. None of the four other SNPs displayed significantly different allele frequencies between the populations.

When analyzing all three populations, none of the 40 subjects homozygous for the rapid $C Y P 2 C 19 * 17$ allele carried the defective $C Y P 2 C 8 * 3, C Y P 2 C 9 * 2$ or $C Y P 2 C 9 * 3$ alleles. In addition, none of the 9 subjects homozygous for $C Y P 2 C 8 * 3$ carried $C Y P 2 C 19 * 17$ and none of the 20 subjects homozygous for $C Y P 2 C 9^{*} 2$ and/or CYP2C $9 * 3$ carried $C Y P 2 C 19 * 17$.

The linkage disequilibrium between the five analysed SNPs as based on Haploview calculations is visualized in Figure 2. The calculations show complete LD $\left(\mathrm{D}^{\prime}=1\right)$ between $C Y P 2 C 19^{*} 17$ and the four other allelic variants. Complete linkage disequilibrium was also observed between CYP2C19*2 and the two CYP2C9 alleles $C Y P 2 C 9 * 2$ and $C Y P 2 C 9 * 3$. The analysis also displays strong linkage disequilibrium between $C Y P 2 C 9 * 2$ and $C Y P 2 C 8^{*} 3\left(\mathrm{D}^{\prime}=0.92\right)$.

Ten $C Y P 2 C$ haplotypes were inferred (Table 3 ). The $C Y P 2 C$ haplotype frequencies predicted by PHASE and STATA were almost identical. Six of the 
haplotypes (No.1-5 and 9) account for 99\% of the haplotypes. The most frequent haplotype (No. 1) with an inferred frequency of $49 \%$ carries the $C Y P 2 C 8 * 1$, $C Y P 2 C 9^{*} 1$ and $C Y P 2 C 19^{*} 1$ alleles. The second most frequent haplotype (No. 2) with an inferred frequency of $19 \%$ is composed by $C Y P 2 C 19 * 17, C Y P 2 C 8 * 1$ and CYP2C9*1 wildtype alleles, and is representing $99.7 \%$ (342 out of 343 ) of all predicted CYP2C19*17-containing haplotypes. In one Norwegian subject, a single variant haplotype with $C Y P 2 C 19 * 17$ in combination with $C Y P 2 C 8 * 3$ was inferred, thus leading to an estimated haplotype frequency of $<0.001$ in the total material of 896 subjects (Table 2). The previously reported linkage disequilibrium between $C Y P 2 C 9 * 2$ and $C Y P 2 C 8 * 3$ presented by Yasar et al. [25] was also supported by our data. In detail, $94 \%$ (144 out of 154 ) of the haplotypes with $C Y P 2 C 8 * 3$ were also predicted to carry $C Y P 2 C 9 * 2$, and $79 \%$ (144 out of 183) of the haplotypes with CYP2C $9 * 2$ were also predicted to carry $C Y P 2 C 8 * 3$.

\section{Discussion}

This study provides support to the hypothesis of a linkage disequilibrium between $C Y P 2 C 19 * 17$ and functional $C Y P 2 C$ alleles. This hypothesis was first expressed by Baldwin et al. [19] but was based on relatively limited data. Further indications can be found by reviewing the genotype information presented by Rudberg et al. [22]. In the present study, we found that $C Y P 2 C 19 * 17$ is predicted to be almost exclusively present together with wild type alleles of $C Y P 2 C 8$ and $C Y P 2 C 9$, thus mediating rapid metabolism of $\mathrm{CYP} 2 \mathrm{C} 19$ substrates and normal (mostly referred to as extensive) metabolism of $\mathrm{CYP} 2 \mathrm{C} 8$ and $\mathrm{CYP} 2 \mathrm{C} 9$ substrates.

The prediction of one haplotype out of the 343 CYP2C19*17-containing haplotypes that exists in combination with $C Y P 2 C 8 * 3$ must be recognized. However the existence of these two variants on separate haplotypes is still a theoretic possibility, although predicted to be rare. Nevertheless, the clinical picture is clear showing that subjects with $C Y P 2 C 19 * 17$ that confers a rapid metabolism of CYP2C19 substrates, are likely to display extensive metabolic capacity toward other CYP2C substrates.

This study also confirms the linkage between $C Y P 2 C 9 * 2$ and $C Y P 2 C 8 * 3$ with similar 
correlation percentages as previously shown by Yasar et al. [25]. Thus, poor metabolisers of CYP2C9 substrate drugs are also likely to poorly metabolise CYP2C8 substrates. It is interesting to note that across the three genes CYP2C19, CYP2C9 and CYP2C8, the five SNPs examined occur in six distinct haplotypes $99 \%$ of the time and further that these haplotypes exclusively carry none or just a single SNP except for haplotype No.9 characterized by two SNPs. This is in accordance with the notion that SNPs are introduced to the genome as a single mutation occurring at a single point in time in a single individual and vertically propagated to the population. In future pharmacogenetic studies it might be worthwhile to consider these haplotypes as an alternative to the individual SNPs as this approach might offer a more powerful design that can possibly reveal effects of interplay between cis variants, which is impossible in simple analysis of individual SNPs.

The current study supports the general assumption that the Nordic populations have a relatively similar distribution of cytochrome $\mathrm{P} 450$ genotypes. The

CYP2C19*17 allele was first reported in Swedes with a frequency of $18 \%$ [18], but a

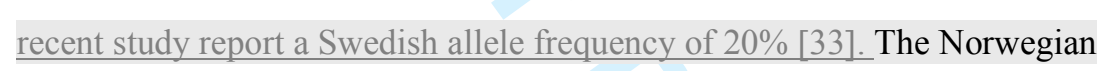

CYP 2 C $19 * 17$ allele frequency of $22 \%$ in the current study of healthy volunteers is identical with the reported frequency in 166 Norwegian psychiatric patients [22], and similar to that observed in the Danish subjects of the present study $(20 \%)$. The Faroese population had a statistically significant lower allele frequency of $15 \%$, but no correction for multiple testing was done. A similar allele frequency of $20 \%$ was found in Greek population [34] and in African populations: 18\% in Ethiopians [18] and $17 \%$ in Ugandans [35]. In Asian populations very low frequencies of CYP2C19*17 has been reported: $4 \%$ in Chinese $\lceil 18\rceil, 1 \%$ in Japanese $\lceil 36\rceil$ and $0.3 \%$ in Koreans [33]. On the other hand, the frequency is apparently higher in Central Europe; $25 \%$ in a German breast cancer population [37] and 28\% in a population of Polish peptic ulcer patients [38]. Overall, CYP2C19*17 must be considered prevalent in all the Nordic populations studied here, and the frequency of subjects homozygous Comment [RP4]: More info of CYP2C19*17 allele freq in other for $C Y P 2 C 19 * 17$ only ranged from 3.5 to $5.1 \%$ in the studied material.

In conclusion, we have in the current study identified a common haplotype in the Nordic population carrying the $C Y P 2 C 19 * 17, C Y P 2 C 8 * 1$ and $C Y P 2 C 9 * 1$ alleles, thus representing a haplotype encoding efficient metabolism of all drugs that are 
1

substrates for CYP2C enzymes. The CYP2C19*17 genotype could thus be used as a determinant for extensive metabolism of CYP2C substrates in Nordic subjects.

\section{Acknowledgements}

This research was supported in part by grants from The Swedish Research Council, Torsten and Ragnar Söderbergs Stiftelser, Karolinska Institutet, The Danish Research Council for Health and Disease, and The Lundbeck Foundation. We thank Pernille Jordan for analytical expertise. 


\section{References}

1. Ingelman-Sundberg M (2004) Human drug metabolising cytochrome P450 enzymes: properties and polymorphisms. Naunyn Schmiedebergs Arch Pharmacol 369:89-104

2. Niwa T, Murayama N, Yamazaki H (2009) Oxidation of Endobiotics Mediated by Xenobiotic-metabolizing Forms of Human Cytochrome P450. Curr Drug Metab 10:700-712

3. Goldstein JA, de Morais SM (1994) Biochemistry and molecular biology of the human CYP2C subfamily. Pharmacogenetics 4:285-99

4. Goldstein JA (2001) Clinical relevance of genetic polymorphisms in the human CYP2C subfamily. Br J Clin Pharmacol 52:349-55

5. Ingelman-Sundberg M, Sim SC, Gomez A, Rodriguez-Antona C. (2007) Influence of cytochrome $\mathrm{P} 450$ polymorphisms on drug therapies: pharmacogenetic, pharmacoepigenetic and clinical aspects. Pharmacol Ther 116:496-526.

6. Romkes M, Faletto MB, Blaisdell JA, Raucy JL, Goldstein JA (1991) Cloning and expression of complementary DNAs for multiple members of the human cytochrome P450IIC subfamily. Biochemistry 30:3247-55

7. Totah RA, Rettie AE (2005) Cytochrome P450 2C8: substrates, inhibitors, pharmacogenetics, and clinical relevance. Clin Pharmacol Ther 77:341-52.

8. http://www.cypalleles.ki.se/cyp2c8.htm assessed in June 2010

9. Dai D, Zeldin DC, Blaisdell JA, Chanas B, Coulter SJ, Ghanayem BI, Goldstein JA (2001) Polymorphisms in human CYP2C8 decrease metabolism of the anticancer drug paclitaxel and arachidonic acid. Pharmacogenetics 11:597-607

10. Bergmann TK, Vach W, Gréen H, Karlsson MO, Friberg L, Nielsen F, Pedersen RS, Mirza MR, Brasch-Andersen C, Brosen K (2010) Impact of CYP2C8*3 on paclitaxel clearance: a population pharmacokinetic and pharmacogenomic study in 93 patients with ovarian cancer. Pharmacogenomics J (April 6, Epub ahead of print)

11. Miners JO, Birkett DJ (1998) Cytochrome P4502C9: an enzyme of major importance in human drug metabolism. Br J Clin Pharmacol 45:525-38

12. http://www.cypalleles.ki.se/cyp2c9.htm assessed in June 2010 
13. King BP, Khan TI, Aithal GP, Kamali F, Daly AK (2004) Upstream and coding region CYP2C9 polymorphisms: correlation with warfarin dose and metabolism. Pharmacogenetics 14:813-22.

14. Pedersen RS, Verstuyft C, Becquemont L, Jaillon P, Brøsen K (2004) Cytochrome P4502C9 (CYP2C9) genotypes in a Nordic population in Denmark. Basic Clin Pharmacol Toxicol 94:151-152

15. http://www.cypalleles.ki.se/cyp2c19.htm assessed in June 2010

16. Wilkinson GR, Guengerich FP, Branch RA (1989) Genetic polymorphism of Smephenytoin hydroxylation. Pharmacol Ther 43:53-76

17. de Morais SM, Wilkinson GR, Blaisdell J, Nakamura K, Meyer UA, Goldstein JA (1994) The major genetic defect responsible for the polymorphism of Smephenytoin metabolism in humans. J Biol Chem 269:15419-22

18. Sim SC, Risinger C, Dahl ML, Aklillu E, Christensen M, Bertilsson L, IngelmanSundberg M (2006) A common novel CYP2C19 gene variant causes ultrarapid drug metabolism relevant for the drug response to proton pump inhibitors and antidepressants. Clin Pharmacol Ther 79:103-13

19. Baldwin RM, Ohlsson S, Pedersen RS, Mwinyi J, Ingelman-Sundberg M, Eliasson E, Bertilsson L (2008) Increased omeprazole metabolism in carriers of the CYP2C19*17 allele; a pharmacokinetic study in healthy volunteers. Br J Clin Pharmacol 65:767-74

20. Ohlsson Rosenborg S, Mwinyi J, Andersson M, Baldwin RM, Pedersen RS, Sim SC, Bertilsson L, Ingelman-Sundberg M, Eliasson (2008) Kinetics of omeprazole and escitalopram in relation to the CYP2C19*17 allele in healthy subjects. Eur J Clin Pharmacol 64:1175-9

21. Sibbing D, Koch W, Gebhard D, Schuster T, Braun S, Stegherr J, Morath T, Schömig A, von Beckerath N, Kastrati A. (2010) Cytochrome 2C19*17 allelic variant, platelet aggregation, bleeding events, and stent thrombosis in clopidogreltreated patients with coronary stent placement. Circulation.;121:512-8.

22. Rudberg I, Mohebi B, Hermann M, Refsum H, Molden E (2008) Impact of the ultrarapid CYP2C19*17 allele on serum concentration of escitalopram in psychiatric patients. Clin Pharmacol Ther 83:322-7

23. Ahmadi KR, Weale ME, Xue ZY, Soranzo N, Yarnall DP, Briley JD, Maruyama Y, Kobayashi M, Wood NW, Spurr NK, Burns DK, Roses AD, Saunders AM, 
Goldstein DB (2005) A single-nucleotide polymorphism tagging set for human drug metabolism and transport. Nat Genet 37:84-9

24. Walton R, Kimber M, Rockett K, Trafford C, Kwiatkowski D, Sirugo G (2005) Haplotype block structure of the cytochrome P450 CYP2C gene cluster on chromosome 10. Nat Genet 37:915-6

25. Yasar U, Lundgren S, Eliasson E, Bennet A, Wiman B, de Faire U, Rane A (2002) Linkage between the CYP2C8 and CYP2C9 genetic polymorphisms. Biochem Biophys Res Commun 299:25-8

26. Mamiya K, Ieiri I, Miyahara S, Imai J, Furuumi H, Fukumaki Y, Ninomiya H, Tashiro N, Yamada H, Higuchi S (1998) Association of polymorphisms in the cytochrome P450 (CYP) 2C19 and 2C18 genes in Japanese epileptic patients. Pharmacogenetics 8:87-90

27. Halling J, Petersen MS, Damkier P, Nielsen F, Grandjean P, Weihe Pál, Lundgren S, Lundblad MS, Brøsen K (2005) Polymorphsims of CYP2D6, CYP2C19, CYP2C9, CYP2C8 in the Faroese population. Eur J Clin Pharmacol 61:491-497

28. Heimdal K, Andersen TI, Skrede M, Fosså SD, Berg K, Børresen AL (1995) Association studies of estrogen receptor polymorphisms in a Norwegian testicular cancer population. Cancer Epidemiol Biomarkers Prev 4(2):123-6

29. Tefre T, Daly AK, Armstrong M, Leathart JB, Idle JR, Brøgger A, Børresen AL (1994) Genotyping of the CYP2D6 gene in Norwegian lung cancer patients and controls. Pharmacogenetics 4(2):47-57

30. Barrett JC, Fry B, Maller J, Daly MJ (2005) Haploview: analysis and visualization of LD and haplotype maps. Bioinformatics 21:263-265

31. Stephens M, Smith NJ, Donnelly P (2001) A new statistical method for haplotype reconstruction from population data. Am J Hum Genet 68: 978-989

32. Stephens M, Scheet $P$ (2005) Accounting for decay of linkage disequilibrium in haplotype inference and missing-data imputation. Am J Hum Genet 76:449-462

33. Ramsjö M, Aklillu E, Bohman L, Ingelman-Sundberg M, Roh HK, Bertilsson L (2010) CYP2C19 activity comparison between Swedes and Koreans: effect of genotype, sex, oral contraceptive use, and smoking. Eur J Clin Pharmacol (Epub ahead of print) 
34. Ragia G, Arvanitidis KI, Tavridou A, Manolopoulos VG (2009) Need for reassessment of reported CYP2C19 allele frequencies in various populations in view of CYP2C19*17 discovery: the case of Greece. Pharmacogenomics 10:43-9.

35. Miura J, Obua C, Abbo C, Kaneko S, Tateishi T (2009) Cytochrome P450 2C19 genetic polymorphisms in Ugandans. Eur J Clin Pharmacol 65: 319-20

36. Sugimoto K, Uno T, Yamazaki H, Tateishi T (2008) Limited frequency of the CYP2C19*17 allele and its minor role in a Japanese population. Br J Clin Pharmacol 65:437-439.

37. Justenhoven C, Hamann U, Pierl CB, Baisch C, Harth V, Rabstein S, Spickenheuer A, Pesch B, Brüning T, Winter S, Ko YD, Brauch H (2009) CYP2C19*17 is associated with decreased breast cancer risk. Breast Cancer Res Treat 115:391-6

38. Gawrońska-Szklarz B, Siuda A, Kurzawski M, Bielicki D, Marlicz W, Droździk M (2010) Effects of CYP2C19, MDR1, and interleukin 1-B gene variants on the eradication rate of Helicobacter pylori infection by triple therapy with 


\title{
Linkage disequilibrium between the $C Y P 2 C 19 * 17$ allele and wildtype $C Y P 2 C 8$ and $C Y P 2 C 9$ alleles: Identification of CYP2C haplotypes in healthy Nordic populations
}

\author{
Rasmus S. Pedersen ${ }^{1,2}$, Charlotte Brasch-Andersen ${ }^{1}$ Sarah C. Sim ${ }^{2}$, Troels \\ K. Bergmann ${ }^{1}$, Jónrit Halling ${ }^{1,3}$, Maria S. Petersen ${ }^{1,3}$, Pál Weihe ${ }^{3}$, Hege \\ Edvardsen $^{4,5}$, Vessela N. Kristensen ${ }^{4,5,6}, \mathrm{Kim} \mathrm{Br} \operatorname{sen}^{1}$ and Magnus \\ Ingelman-Sundberg ${ }^{2}$
}

${ }^{1}$ Institute of Public Health, Clinical Pharmacology, University of Southern Denmark, Odense, Denmark

${ }^{2}$ Section of Pharmacogenetics, Department of Physiology and Pharmacology, Karolinska Institutet, Stockholm, Sweden

${ }^{3}$ Department of Occupational Medicines and Public Health, The Faroese Hospital System, Tòrshavn, Faroe Islands

${ }^{4}$ Department of Genetics, Institute of Cancer Research, Oslo University Hospital Radiumhospitalet, Oslo, Norway

${ }^{5}$ Institute of Clinical Medicine, University of Oslo, Oslo, Norway

${ }^{6}$ EpiGen, Institute for Clinical Medicine, Akershus University Hospital, Oslo, Norway

Correspondence:

Rasmus Steen Pedersen, Institute of Public Health, Clinical Pharmacology, University of Southern Denmark, Odense, Denmark. E-mail: rpedersen@ health.sdu.dk. Phone: +45 65503305. Fax: +45 65916089 


\section{Introduction}

Human cytochrome P450 2C (CYP2C) enzymes are responsible for the metabolism of approximately $25 \%$ of clinically used drugs [1] and some endogenous substances such as arachidonic acid [2]. The human CYP2C subfamily includes CYP2C8, CYP2C9, CYP2C18 and CYP2C19 that are homologous and share more than $80 \%$ amino acid sequence identity [3]. However, only CYP2C8, CYP2C9 and CYP2C19 are considered of clinical importance [4], since CYP2C18 mRNA is detected at relatively low amounts [5]. The entire $C Y P 2 C$ gene locus spans approximately $500 \mathrm{~kb}$ on chromosome 10 with the gene order Cen-2C18-2C19-2C9-2C8-Tel (Figure 1) and each of the genes consist of nine exons with conserved exon/intron boundaries [6]. CYP2C8, CYP2C9 and CYP2C19 exhibit clinically important genetic polymorphism as a result of single nucleotide polymorphisms (SNPs) (www.cypalleles.ki.se).

CYP2C8 catalyzes the metabolism of several clinically used drugs such as the anti-cancer drug paclitaxel, the anti-arrhythmic drug amiodarone, the antidiabetic drug repaglinide, and the thiazolidinediones rosiglitazone and troglitazone [7]. Fourteen allelic variants of CYP2C8 have been described of which some cause poor metabolism [8]. CYP2C8*3 is a quantitatively and functionally relevant variant allele in the Caucasian population with a reported frequency of $10-23 \%$ but rare or absent in Asian and African populations [5]. CYP2C $8 * 3$ is defined by two amino acid substitutions in exon 3 and exon 8 (Table 1), respectively, causing decreased paclitaxel turnover [9] and decreased paclitaxel clearance in vivo [10].

CYP2C9 is among the most important drug metabolizing enzymes in humans. It is involved in the metabolism of several important drugs including phenytoin, losartan, $(S)$-warfarin, tolbutamide and numerous NSAIDs [11]. Of the 34 allelic variants that have been described [12], the two clinically most important variant alleles are $C Y P 2 C 9 * 2$ and $C Y P 2 C 9 * 3$, which both cause a defective CYP2C9 enzyme (Table 1)[13]. The allele frequencies of $C Y P 2 C 9 * 2$ and $C Y P 2 C 9 * 3$ are approximately $10-15 \%$ and 5-10\%, respectively, in European populations [14].

CYP2C19 is another important drug metabolizing enzyme encoded by a highly polymorphic gene [15]. The racemic anticonvulsant drug mephenytoin is the classic probe drug where the 4-hydroxylation of the $(S)$-enantiomer is catalysed by CYP2C19. Furthermore, a range of clinically important drugs including diazepam, 
omeprazole and other proton pump inhibitors, the antidepressants citalopram, escitalopram and imipramine, the antimalarial drugs proguanil and chlorproguanil, the $\beta$-adrenoceptor blocker propranolol, and the antiplatelet drug clopidogrel are metabolized or bioactivated by CYP2C19. Population studies have shown that individuals that are homozygous for the inactivating allele $C Y P 2 C 19 * 2$ that leads to a splicing defect (Table 1), are phenotypic poor metabolizers of CYP2C19 substrates $[5,16,17]$. The CYP2C19 poor metabolizers only represent $3-5 \%$ of Caucasian populations, but is found in $12-23 \%$ of Asian populations [3]. In recent years, much attention has focused on the allele $C Y P 2 C 19 * 17$ that correlates with high in vivo CYP2C19 activity and is present at an allele frequency of $18 \%$ in a Swedish healthy population [18]. The initial finding of a rapid drug metabolism phenotype was later supported by a clear association of lower plasma concentration of omeprazole and escitalopram in subjects homozygous for $C Y P 2 C 19 * 17[19,20]$. Interestingly, $C Y P 2 C 19 * 17$ also leads to increased bioactivation of the antiplatelet drug clopidogrel that causes an almost 4-fold higher risk of bleeding complications in $C Y P 2 C 19 * 17$ homozygotes, but no beneficial antithrombotic effect for patients undergoing percutaneous coronary intervention [21]. As opposed to subjects homozygous for the $C Y P 2 C 19 * 1$ allele, subjects homozygous for $C Y P 2 C 19 * 17$ display a very low interindividual variation in CYP2C19 metabolism $[19,22]$. The rapid phenotype caused by $C Y P 2 C 19 * 17$ has been explained by a recruitment of transcription factor(s) by the $-806 \mathrm{C}>\mathrm{T}$ conversion (Table 1 ) in the gene promotor region that causes an increased transcriptional rate [18]. A hypothesis is that $C Y P 2 C 19 * 17$ is also a haplotype marker within the $C Y P 2 C$ locus [19]. In fact, haplotype block structures at the $C Y P 2 C$ locus have been described $[23,24]$. Almost all subjects carrying $C Y P 2 C 8 * 3$ also carry $C Y P 2 C 9 * 2$ and three quarters of all subjects carrying $C Y P 2 C 9 * 2$ also carry $C Y P 2 C 8 * 3$ [25]. $C Y P 2 C 19 * 2$ and $C Y P 2 C 19 * 3$ has also been shown to be linked with CYP2C18 mutations in Japanese subjects [26].

The aim of this study was to determine important $C Y P 2 C$ genotypes with special focus on $C Y P 2 C 19 * 17$ in healthy Nordic populations, and to investigate the linkage disequilibrium between them.

\section{Methods}




\section{Samples}

DNA samples from 276 healthy volunteers living around Odense in Denmark and previously genotyped for $C Y P 2 C 9 * 2$ and $C Y P 2 C 9 * 3$ [14], and 311 Faroese samples from healthy volunteers previously genotyped for $C Y P 2 C 8 * 3, C Y P 2 C 9 * 2$, $C Y P 2 C 9 * 3$ and $C Y P 2 C 19 * 2$ [27] were included in this study. Furthermore, DNA samples from 328 Norwegian Caucasian blood donors that had not been genotyped for $C Y P 2 C$ variants were included $[28,29]$.

\section{Genotyping}

A total of 915 DNA samples from three different populations were available for genotyping and the aim was to cover the five clinically important $C Y P 2 C$ allelic variants; $C Y P 2 C 8 *, C Y P 2 C 9 * 2, C Y P 2 C 9 * 3, C Y P 2 C 19 * 2$ and $C Y P 2 C 19 * 17$. All 276 DNA samples from Denmark [14] were successfully genotyped for $C Y P 2 C 8 * 3$, $C Y P 2 C 19 * 2$ and $C Y P 2 C 19 * 17$ and all the 311 Faroese samples were successfully genotyped for $C Y P 2 C 19 * 17$. Of the 328 Norwegian DNA samples, 309 were successfully genotyped for all five $C Y P 2 C$ variants. The analyses were performed using Applied Biosystems TaqMan® SNP genotyping assays (Table 1) according to the guidelines and conducted on an Applied Biosystems StepOne Plus apparatus or an Applied Biosystems 7500 Real Time PCR apparatus.

\section{Statistics}

Possible deviation from Hardy Weinberg equilibrium was tested for each SNP with Pearsons Chi-Square test with a level of significance of 5\%. Overall differences of allele frequencies between the populations were also tested by Chi-Squared test with a level of significance of 5\%. "Head to head" comparison between the populations was tested with Fisher's exact test with a level of significance of 5\%.

\section{Linkage disequilibrium and haplotype inference}

The software Haploview was used to visualize the structure of pair-wise linkage disequilibrium (LD) between the SNPs (in terms of Lewontin's D') [30]. Individual haplotypes were inferred by use of the five $C Y P 2 C$ SNPs and software package PHASE version 2.1 [31,32]. This software infers haplotypes from population genotype data using a Bayesian statistical method. We performed PHASE analyses 
with default settings ten times with different random seed. Additionally, haplotype frequencies were estimated using the expectation maximation algorithm (EM) in STATA10 (StataCorp, Texas, USA).

\section{Results}

We performed genotyping of $C Y P 2 C 8 * 3, C Y P 2 C 9 * 2, C Y P 2 C 9 * 3, C Y P 2 C 19 * 2$ and CYP2C19*17 in three different Nordic populations. The genotype and allele frequencies in the Danish, Faroese and Norwegian samples are presented in Table 2. All SNPs in all three populations were in Hardy-Weinberg equilibrium displaying $\chi^{2}$ values less than 3.84 .

An overall significant difference in allele frequency of $C Y P 2 C 19 * 17$ was found between the populations $(\mathrm{P}=0.010)$. The allele frequency of $15 \%$ in the Faroese population $(\mathrm{n}=311)$ was lower than the $20 \%$ in the Danish population $(\mathrm{n}=276)$ $(\mathrm{P}=0.038)$ and the $22 \%$ in the Norwegian population $(\mathrm{n}=309, \mathrm{P}=0.003)$. No statistically significant difference between the Danish and the Norwegian population was found. None of the four other SNPs displayed significantly different allele frequencies between the populations.

When analyzing all three populations, none of the 40 subjects homozygous for the rapid $C Y P 2 C 19 * 17$ allele carried the defective $C Y P 2 C 8 * 3, C Y P 2 C 9 * 2$ or $C Y P 2 C 9 * 3$ alleles. In addition, none of the 9 subjects homozygous for $C Y P 2 C 8 * 3$ carried $C Y P 2 C 19 * 17$ and none of the 20 subjects homozygous for $C Y P 2 C 9 * 2$ and/or CYP2C9*3 carried $C Y P 2 C 19 * 17$.

The linkage disequilibrium between the five analysed SNPs as based on Haploview calculations is visualized in Figure 2. The calculations show complete LD $\left(\mathrm{D}^{\prime}=1\right)$ between $C Y P 2 C 19 * 17$ and the four other allelic variants. Complete linkage disequilibrium was also observed between $C Y P 2 C 19 * 2$ and the two CYP2C9 alleles $C Y P 2 C 9 * 2$ and $C Y P 2 C 9 * 3$. The analysis also displays strong linkage disequilibrium between $C Y P 2 C 9 * 2$ and $C Y P 2 C 8 * 3\left(\mathrm{D}^{\prime}=0.92\right)$.

Ten $C Y P 2 C$ haplotypes were inferred (Table 3). The $C Y P 2 C$ haplotype frequencies predicted by PHASE and STATA were almost identical. Six of the 
haplotypes (No.1-5 and 9) account for 99\% of the haplotypes. The most frequent haplotype (No. 1) with an inferred frequency of $49 \%$ carries the $C Y P 2 C 8^{*} 1$, $C Y P 2 C 9 * 1$ and $C Y P 2 C 19 * 1$ alleles. The second most frequent haplotype (No. 2) with an inferred frequency of $19 \%$ is composed by $C Y P 2 C 19 * 17, C Y P 2 C 8 * 1$ and CYP2C9*1 wildtype alleles, and is representing $99.7 \%$ (342 out of 343 ) of all predicted $C Y P 2 C 19 * 17$-containing haplotypes. In one Norwegian subject, a single variant haplotype with $C Y P 2 C 19 * 17$ in combination with $C Y P 2 C 8 * 3$ was inferred, thus leading to an estimated haplotype frequency of $<0.001$ in the total material of 896 subjects (Table 2). The previously reported linkage disequilibrium between $C Y P 2 C 9 * 2$ and $C Y P 2 C 8 * 3$ presented by Yasar et al. [25] was also supported by our data. In detail, $94 \%$ (144 out of 154) of the haplotypes with $C Y P 2 C 8 * 3$ were also predicted to carry $C Y P 2 C 9 * 2$, and $79 \%$ (144 out of 183) of the haplotypes with $C Y P 2 C 9 * 2$ were also predicted to carry $C Y P 2 C 8 * 3$.

\section{Discussion}

This study provides support to the hypothesis of a linkage disequilibrium between $C Y P 2 C 19 * 17$ and functional $C Y P 2 C$ alleles. This hypothesis was first expressed by Baldwin et al. [19] but was based on relatively limited data. Further indications can be found by reviewing the genotype information presented by Rudberg et al. [22]. In the present study, we found that $C Y P 2 C 19 * 17$ is predicted to be almost exclusively present together with wild type alleles of $C Y P 2 C 8$ and $C Y P 2 C 9$, thus mediating rapid metabolism of CYP2C19 substrates and normal (mostly referred to as extensive) metabolism of CYP2C8 and CYP2C9 substrates.

The prediction of one haplotype out of the 343 CYP2C19*17-containing haplotypes that exists in combination with $C Y P 2 C 8 * 3$ must be recognized. However the existence of these two variants on separate haplotypes is still a theoretic possibility, although predicted to be rare. Nevertheless, the clinical picture is clear showing that subjects with $C Y P 2 C 19 * 17$ that confers a rapid metabolism of CYP2C19 substrates, are likely to display extensive metabolic capacity toward other CYP2C substrates.

This study also confirms the linkage between $C Y P 2 C 9 * 2$ and $C Y P 2 C 8 * 3$ with similar 
correlation percentages as previously shown by Yasar et al. [25]. Thus, poor metabolisers of CYP2C9 substrate drugs are also likely to poorly metabolise CYP2C8 substrates. It is interesting to note that across the three genes CYP2C19, CYP2C9 and CYP2C8, the five SNPs examined occur in six distinct haplotypes 99\% of the time and further that these haplotypes exclusively carry none or just a single SNP except for haplotype No.9 characterized by two SNPs. This is in accordance with the notion that SNPs are introduced to the genome as a single mutation occurring at a single point in time in a single individual and vertically propagated to the population. In future pharmacogenetic studies it might be worthwhile to consider these haplotypes as an alternative to the individual SNPs as this approach might offer a more powerful design that can possibly reveal effects of interplay between cis variants, which is impossible in simple analysis of individual SNPs.

The current study supports the general assumption that the Nordic populations have a relatively similar distribution of cytochrome P450 genotypes. The CYP2C19*17 allele was first reported in Swedes with a frequency of $18 \%$ [18], but a recent study report a Swedish allele frequency of $20 \%$ [33]. The Norwegian CYP2C19*17 allele frequency of $22 \%$ in the current study of healthy volunteers is identical with the reported frequency in 166 Norwegian psychiatric patients [22], and similar to that observed in the Danish subjects of the present study (20\%). The Faroese population had a statistically significant lower allele frequency of $15 \%$, but no correction for multiple testing was done. A similar allele frequency of $20 \%$ was found in Greek population [34] and in African populations: 18\% in Ethiopians [18] and $17 \%$ in Ugandans [35]. In Asian populations very low frequencies of CYP2C19*17 has been reported: $4 \%$ in Chinese [18], $1 \%$ in Japanese [36] and $0.3 \%$ in Koreans [33]. On the other hand, the frequency is apparently higher in Central Europe; $25 \%$ in a German breast cancer population [37] and $28 \%$ in a population of Polish peptic ulcer patients [38]. Overall, CYP2C19*17 must be considered prevalent in all the Nordic populations studied here, and the frequency of subjects homozygous for $C Y P 2 C 19 * 17$ only ranged from 3.5 to $5.1 \%$ in the studied material.

In conclusion, we have in the current study identified a common haplotype in the Nordic population carrying the $C Y P 2 C 19 * 17, C Y P 2 C 8 * 1$ and $C Y P 2 C 9 * 1$ alleles, thus representing a haplotype encoding efficient metabolism of all drugs that are 
substrates for CYP2C enzymes. The $C Y P 2 C 19 * 17$ genotype could thus be used as a determinant for extensive metabolism of CYP2C substrates in Nordic subjects.

\section{Acknowledgements}

This research was supported in part by grants from The Swedish Research Council, Torsten and Ragnar Söderbergs Stiftelser, Karolinska Institutet, The Danish Research Council for Health and Disease, and The Lundbeck Foundation. We thank Pernille Jordan for analytical expertise. 


\section{References}

1. Ingelman-Sundberg M (2004) Human drug metabolising cytochrome P450 enzymes: properties and polymorphisms. Naunyn Schmiedebergs Arch Pharmacol 369:89-104

2. Niwa T, Murayama N, Yamazaki H (2009) Oxidation of Endobiotics Mediated by Xenobiotic-metabolizing Forms of Human Cytochrome P450. Curr Drug Metab 10:700-712

3. Goldstein JA, de Morais SM (1994) Biochemistry and molecular biology of the human CYP2C subfamily. Pharmacogenetics 4:285-99

4. Goldstein JA (2001) Clinical relevance of genetic polymorphisms in the human CYP2C subfamily. Br J Clin Pharmacol 52:349-55

5. Ingelman-Sundberg M, Sim SC, Gomez A, Rodriguez-Antona C. (2007) Influence of cytochrome $\mathrm{P} 450$ polymorphisms on drug therapies: pharmacogenetic, pharmacoepigenetic and clinical aspects. Pharmacol Ther 116:496-526.

6. Romkes M, Faletto MB, Blaisdell JA, Raucy JL, Goldstein JA (1991) Cloning and expression of complementary DNAs for multiple members of the human cytochrome P450IIC subfamily. Biochemistry 30:3247-55

7. Totah RA, Rettie AE (2005) Cytochrome P450 2C8: substrates, inhibitors, pharmacogenetics, and clinical relevance. Clin Pharmacol Ther 77:341-52.

8. http://www.cypalleles.ki.se/cyp2c8.htm assessed in June 2010

9. Dai D, Zeldin DC, Blaisdell JA, Chanas B, Coulter SJ, Ghanayem BI, Goldstein JA (2001) Polymorphisms in human CYP2C8 decrease metabolism of the anticancer drug paclitaxel and arachidonic acid. Pharmacogenetics 11:597-607

10. Bergmann TK, Vach W, Gréen H, Karlsson MO, Friberg L, Nielsen F, Pedersen RS, Mirza MR, Brasch-Andersen C, Brosen K (2010) Impact of CYP2C8*3 on paclitaxel clearance: a population pharmacokinetic and pharmacogenomic study in 93 patients with ovarian cancer. Pharmacogenomics J (April 6, Epub ahead of print)

11. Miners JO, Birkett DJ (1998) Cytochrome P4502C9: an enzyme of major importance in human drug metabolism. Br J Clin Pharmacol 45:525-38

12. http://www.cypalleles.ki.se/cyp2c9.htm assessed in June 2010 
13. King BP, Khan TI, Aithal GP, Kamali F, Daly AK (2004) Upstream and coding region CYP2C9 polymorphisms: correlation with warfarin dose and metabolism. Pharmacogenetics 14:813-22.

14. Pedersen RS, Verstuyft C, Becquemont L, Jaillon P, Brøsen K (2004) Cytochrome P4502C9 (CYP2C9) genotypes in a Nordic population in Denmark. Basic Clin Pharmacol Toxicol 94:151-152

15. http://www.cypalleles.ki.se/cyp2c19.htm assessed in June 2010

16. Wilkinson GR, Guengerich FP, Branch RA (1989) Genetic polymorphism of Smephenytoin hydroxylation. Pharmacol Ther 43:53-76

17. de Morais SM, Wilkinson GR, Blaisdell J, Nakamura K, Meyer UA, Goldstein JA (1994) The major genetic defect responsible for the polymorphism of Smephenytoin metabolism in humans. J Biol Chem 269:15419-22

18. Sim SC, Risinger C, Dahl ML, Aklillu E, Christensen M, Bertilsson L, IngelmanSundberg M (2006) A common novel CYP2C19 gene variant causes ultrarapid drug metabolism relevant for the drug response to proton pump inhibitors and antidepressants. Clin Pharmacol Ther 79:103-13

19. Baldwin RM, Ohlsson S, Pedersen RS, Mwinyi J, Ingelman-Sundberg M, Eliasson E, Bertilsson L (2008) Increased omeprazole metabolism in carriers of the CYP2C19*17 allele; a pharmacokinetic study in healthy volunteers. Br J Clin Pharmacol 65:767-74

20. Ohlsson Rosenborg S, Mwinyi J, Andersson M, Baldwin RM, Pedersen RS, Sim SC, Bertilsson L, Ingelman-Sundberg M, Eliasson (2008) Kinetics of omeprazole and escitalopram in relation to the CYP2C19*17 allele in healthy subjects. Eur J Clin Pharmacol 64:1175-9

21. Sibbing D, Koch W, Gebhard D, Schuster T, Braun S, Stegherr J, Morath T, Schömig A, von Beckerath N, Kastrati A. (2010) Cytochrome 2C19*17 allelic variant, platelet aggregation, bleeding events, and stent thrombosis in clopidogreltreated patients with coronary stent placement. Circulation.;121:512-8.

22. Rudberg I, Mohebi B, Hermann M, Refsum H, Molden E (2008) Impact of the ultrarapid CYP2C19*17 allele on serum concentration of escitalopram in psychiatric patients. Clin Pharmacol Ther 83:322-7

23. Ahmadi KR, Weale ME, Xue ZY, Soranzo N, Yarnall DP, Briley JD, Maruyama Y, Kobayashi M, Wood NW, Spurr NK, Burns DK, Roses AD, Saunders AM, 
Goldstein DB (2005) A single-nucleotide polymorphism tagging set for human drug metabolism and transport. Nat Genet 37:84-9

24. Walton R, Kimber M, Rockett K, Trafford C, Kwiatkowski D, Sirugo G (2005) Haplotype block structure of the cytochrome P450 CYP2C gene cluster on chromosome 10. Nat Genet 37:915-6

25. Yasar U, Lundgren S, Eliasson E, Bennet A, Wiman B, de Faire U, Rane A (2002) Linkage between the CYP2C8 and CYP2C9 genetic polymorphisms. Biochem Biophys Res Commun 299:25-8

26. Mamiya K, Ieiri I, Miyahara S, Imai J, Furuumi H, Fukumaki Y, Ninomiya H, Tashiro N, Yamada H, Higuchi S (1998) Association of polymorphisms in the cytochrome P450 (CYP) 2C19 and 2C18 genes in Japanese epileptic patients. Pharmacogenetics 8:87-90

27. Halling J, Petersen MS, Damkier P, Nielsen F, Grandjean P, Weihe Pál, Lundgren S, Lundblad MS, Brøsen K (2005) Polymorphsims of CYP2D6, CYP2C19, CYP2C9, CYP2C8 in the Faroese population. Eur J Clin Pharmacol 61:491-497

28. Heimdal K, Andersen TI, Skrede M, Fosså SD, Berg K, Børresen AL (1995) Association studies of estrogen receptor polymorphisms in a Norwegian testicular cancer population. Cancer Epidemiol Biomarkers Prev 4(2):123-6

29. Tefre T, Daly AK, Armstrong M, Leathart JB, Idle JR, Brøgger A, Børresen AL (1994) Genotyping of the CYP2D6 gene in Norwegian lung cancer patients and controls. Pharmacogenetics 4(2):47-57

30. Barrett JC, Fry B, Maller J, Daly MJ (2005) Haploview: analysis and visualization of LD and haplotype maps. Bioinformatics 21:263-265

31. Stephens M, Smith NJ, Donnelly P (2001) A new statistical method for haplotype reconstruction from population data. Am J Hum Genet 68: 978-989

32. Stephens M, Scheet $P$ (2005) Accounting for decay of linkage disequilibrium in haplotype inference and missing-data imputation. Am J Hum Genet 76:449-462

33. Ramsjö M, Aklillu E, Bohman L, Ingelman-Sundberg M, Roh HK, Bertilsson L (2010) CYP2C19 activity comparison between Swedes and Koreans: effect of genotype, sex, oral contraceptive use, and smoking. Eur J Clin Pharmacol (Epub ahead of print) 
34. Ragia G, Arvanitidis KI, Tavridou A, Manolopoulos VG (2009) Need for reassessment of reported CYP2C19 allele frequencies in various populations in view of CYP2C19*17 discovery: the case of Greece. Pharmacogenomics 10:43-9.

35. Miura J, Obua C, Abbo C, Kaneko S, Tateishi T (2009) Cytochrome P450 2C19 genetic polymorphisms in Ugandans. Eur J Clin Pharmacol 65: 319-20

36. Sugimoto K, Uno T, Yamazaki H, Tateishi T (2008) Limited frequency of the CYP2C19*17 allele and its minor role in a Japanese population. Br J Clin Pharmacol 65:437-439.

37. Justenhoven C, Hamann U, Pierl CB, Baisch C, Harth V, Rabstein S, Spickenheuer A, Pesch B, Brüning T, Winter S, Ko YD, Brauch H (2009) CYP2C19*17 is associated with decreased breast cancer risk. Breast Cancer Res Treat 115:391-6

38. Gawrońska-Szklarz B, Siuda A, Kurzawski M, Bielicki D, Marlicz W, Droździk M (2010) Effects of CYP2C19, MDR1, and interleukin 1-B gene variants on the eradication rate of Helicobacter pylori infection by triple therapy with pantoprazole, amoxicillin, and metronidazole. Eur J Clin Pharmacol 66:681-7 
Figure 1

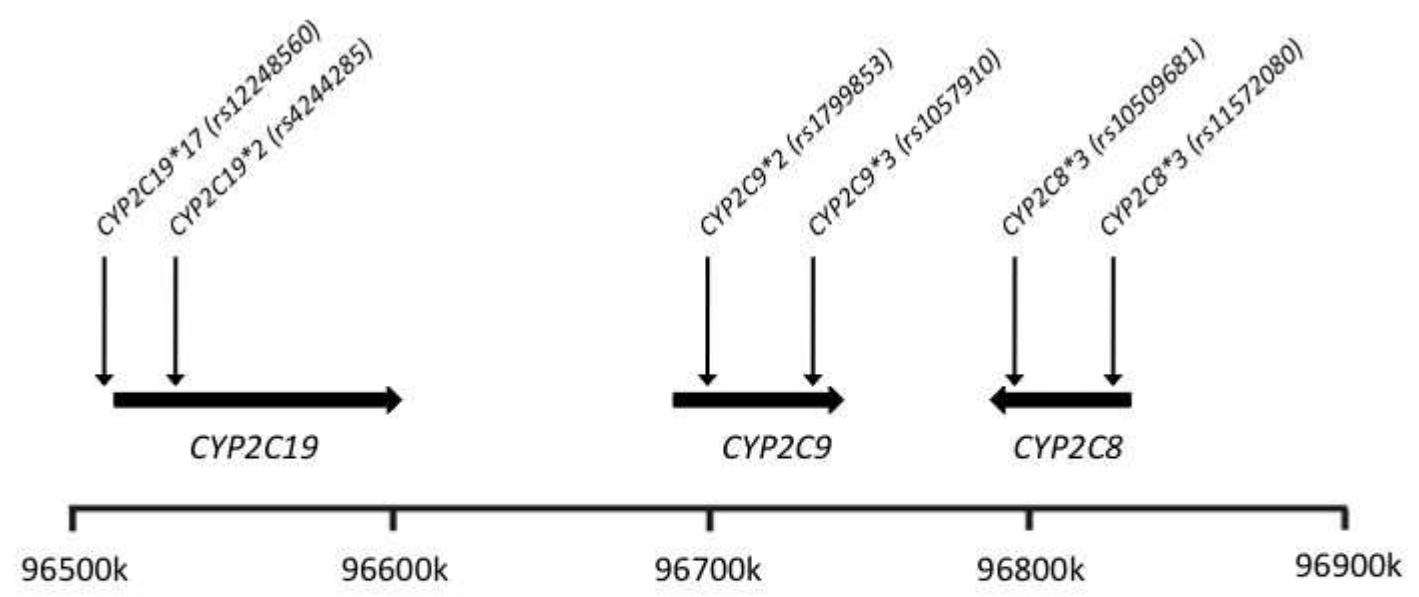

The organisation of $C Y P 2 C 19, C Y P 2 C 9$, and $C Y P 2 C 8$ genes on chromosome 10 as based on the human genome map found at www.ncbi.nlm.nih (build 36.3). Thin arrows indicate the position of the allelic variants analyzed. Thick arrows represent the genes studied indicating the direction of gene transcription. 
Figure 2

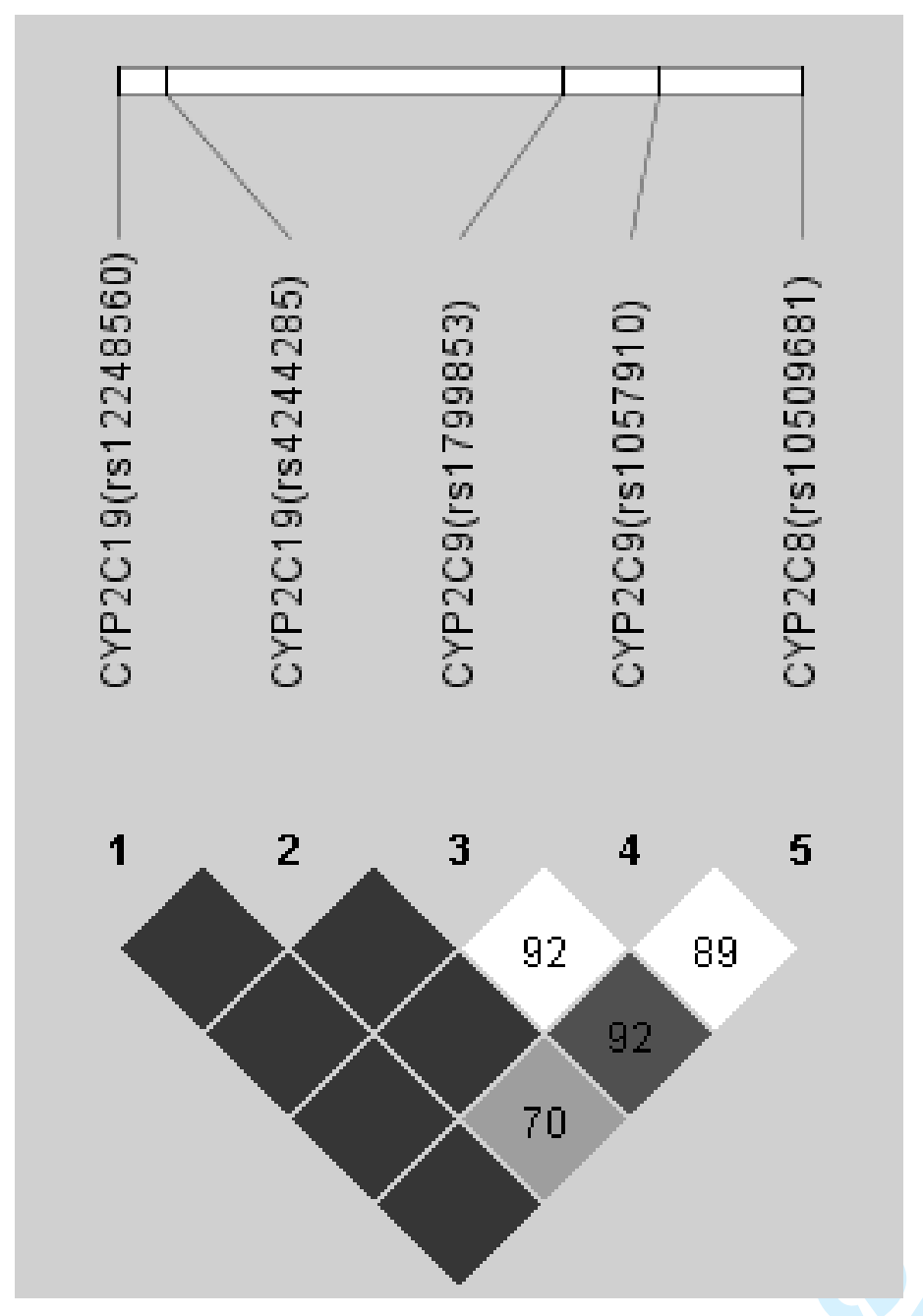

The linkage disequilibrium (LD) map of the 5 SNPs analysed in the current study was created using Haploview. The dark squares without numbers show complete LD (D'=1, LOD > 3.6). 
Table 1

The studied $C Y P 2 C$ allelic variants

\begin{tabular}{|c|c|c|c|c|}
\hline CYP allele & rs number & $\begin{array}{c}\text { Gene } \\
\text { nucleotide change }\end{array}$ & $\begin{array}{c}\text { Protein } \\
\text { Effect }\end{array}$ & $\begin{array}{c}\text { TaqMan }{ }^{\circledR} \\
\text { Assay Number }\end{array}$ \\
\hline СУР2C19*17 & rs 12248560 & $-806 \mathrm{C}>\mathrm{T}$ & $\mathrm{Ile}_{331} \rightarrow \mathrm{Val}$ & C_469857_10 \\
\hline СYР2C19*2 & rs4244285 & $19154 \mathrm{G}>\mathrm{A}$ & Splicing defect & C__25986767_70 \\
\hline CYP2C $9 * 2$ & rs1799853 & $3608 \mathrm{C}>\mathrm{T}$ & $\operatorname{Arg}_{144} \rightarrow$ Lys & C__25986767_10 \\
\hline CYP2C9*3 & rs1057910 & $42614 \mathrm{~A}>\mathrm{C}$ & $\mathrm{Ile}_{359} \rightarrow$ Leu & C__27104892_10 \\
\hline CYP2C $8 * 3$ & rs10509681 & $40411 \mathrm{~A}>\mathrm{G}$ & Lys $_{399} \rightarrow$ Arg & C__25625782_20 \\
\hline CYP2C $8 * 3$ & rs 11572080 & $2130 \mathrm{G}>\mathrm{A}$ & $\operatorname{Arg}_{139} \rightarrow$ Lys & Not tested \\
\hline
\end{tabular}


Table 2

Genotype and allele frequencies of $C Y P 2 C 8, C Y P 2 C 9$ and $C Y P 2 C 19$ allelic SNPs in Danish, Faroese and Norwegian subjects.

\begin{tabular}{|c|c|c|c|c|c|c|}
\hline & \multicolumn{2}{|c|}{ Danish } & \multicolumn{2}{|c|}{ Faroese } & \multicolumn{2}{|c|}{ Norwegian } \\
\hline СУР2C8 & $\begin{array}{c}\text { Number of } \\
\text { subjects }\end{array}$ & Frequency & $\begin{array}{c}\text { Number of } \\
\text { subjects }\end{array}$ & Frequency & $\begin{array}{c}\text { Number of } \\
\text { subjects }\end{array}$ & Frequency \\
\hline CYP2C $8 * 1 / * 1$ & 226 & 0.819 & 268 & 0.862 & 257 & 0.832 \\
\hline$C Y P 2 C 8 * 1 / * 3$ & 45 & 0.163 & 43 & 0.138 & 48 & 0.155 \\
\hline$C Y P 2 C 8 * 3 / * 3$ & 5 & 0.018 & 0 & 0.000 & 4 & 0.013 \\
\hline Allele & $\begin{array}{c}\text { Number of } \\
\text { alleles }\end{array}$ & Frequency & $\begin{array}{c}\text { Number of } \\
\text { alleles }\end{array}$ & Frequency & $\begin{array}{c}\text { Number of } \\
\text { alleles }\end{array}$ & Frequency \\
\hline$C Y P 2 C 8 * 1$ & 497 & 0.900 & 579 & 0.931 & 562 & 0.909 \\
\hline$C Y P 2 C 8 * 3$ & 55 & 0.100 & 43 & 0.069 & 56 & 0.091 \\
\hline СУР2C9 & $\begin{array}{c}\text { Number of } \\
\text { subjects }\end{array}$ & Frequency & $\begin{array}{c}\text { Number of } \\
\text { subjects }\end{array}$ & Frequency & $\begin{array}{c}\text { Number of } \\
\text { subjects }\end{array}$ & Frequency \\
\hline CYP $2 C 9 * 1 / * 1$ & 190 & 0.688 & 228 & 0.733 & 213 & 0.689 \\
\hline CYP $2 C 9 * 1 / * 2$ & 53 & 0.192 & 50 & 0.161 & 55 & 0.178 \\
\hline CYP $2 C 9 * 1 / * 3$ & 23 & 0.083 & 28 & 0.090 & 36 & 0.117 \\
\hline CYP $2 C 9 * 2 / * 2$ & 4 & 0.014 & 0 & 0.000 & 2 & 0.007 \\
\hline СYР $2 C 9 * 3 / * 3$ & 0 & 0.000 & 0 & 0.000 & 1 & 0.003 \\
\hline$C Y P 2 C 9 * 2 / * 3$ & 6 & 0.022 & 5 & 0.016 & 2 & 0.007 \\
\hline Allele & $\begin{array}{c}\begin{array}{c}\text { Number of } \\
\text { alleles }\end{array} \\
\end{array}$ & Frequency & $\begin{array}{c}\begin{array}{c}\text { Number of } \\
\text { alleles }\end{array} \\
\end{array}$ & Frequency & $\begin{array}{c}\begin{array}{c}\text { Number of } \\
\text { alleles }\end{array} \\
\end{array}$ & Frequency \\
\hline$C Y P 2 C 9 * 1$ & 456 & 0.826 & 534 & 0.859 & 517 & 0.837 \\
\hline$C Y P 2 C 9 * 2$ & 67 & 0.121 & 55 & 0.088 & 61 & 0.099 \\
\hline$C Y P 2 C 9 * 3$ & 29 & 0.053 & 33 & 0.053 & 40 & 0.065 \\
\hline СУР2C19 & $\begin{array}{c}\text { Number of } \\
\text { subjects }\end{array}$ & Frequency & $\begin{array}{c}\text { Number of } \\
\text { subjects }\end{array}$ & Frequency & $\begin{array}{c}\text { Number of } \\
\text { subjects }\end{array}$ & Frequency \\
\hline CYP $2 C 19 * 1 / * 1$ & 122 & 0.442 & 143 & 0.460 & 122 & 0.395 \\
\hline CYP $2 C 19 * 1 / * 2$ & 51 & 0.185 & 73 & 0.235 & 62 & 0.201 \\
\hline$C Y P 2 C 19 * 1 / * 17$ & 63 & 0.228 & 51 & 0.164 & 82 & 0.265 \\
\hline CYP $2 C 19 * 2 / * 2$ & 6 & 0.022 & 10 & 0.032 & 4 & 0.013 \\
\hline CYP2C19*17/*17 & 14 & 0.051 & 11 & 0.035 & 15 & 0.049 \\
\hline CYP 2 C19*2/*17 & 20 & 0.073 & 23 & 0.074 & 24 & 0.078 \\
\hline Allele & $\begin{array}{c}\text { Number of } \\
\text { alleles }\end{array}$ & Frequency & $\begin{array}{c}\text { Number of } \\
\text { alleles }\end{array}$ & Frequency & $\begin{array}{c}\text { Number of } \\
\text { alleles }\end{array}$ & Frequency \\
\hline CYP2C19*1 & 358 & 0.649 & 410 & 0.659 & 388 & 0.628 \\
\hline CYP2C19*2 & 83 & 0.150 & 116 & 0.187 & 94 & 0.152 \\
\hline СYР2C19*17 & 111 & 0.201 & 96 & 0.154 & 136 & 0.220 \\
\hline
\end{tabular}


Table 3

Frequency of the 10 haplotypes inferred in the entire study of 896 subjects.

\begin{tabular}{|c|c|c|c|c|c|c|c|c|}
\hline Haplotype No. & CYP2C19*17 & СYР2C19*2 & CYP2C $9 * 2$ & CYP2C $9 * 3$ & CYP2C $8 * 3$ & $\begin{array}{l}\text { Number of } \\
\text { haplotypes }\end{array}$ & $\begin{array}{c}\text { PHASE } \\
\text { frequency }\end{array}$ & $\begin{array}{c}\text { STATA } \\
\text { frequency }\end{array}$ \\
\hline 1 & - & - & - & - & - & 869 & 0.4862 & 0.4866 \\
\hline 2 & $\sqrt{ }$ & - & - & - & - & 342 & 0.1901 & 0.1902 \\
\hline 3 & - & $\sqrt{ }$ & - & - & - & 286 & 0.1589 & 0.1595 \\
\hline 4 & - & - & $\sqrt{ }$ & - & - & 39 & 0.0218 & 0.0219 \\
\hline 5 & - & - & $-\quad 0$ & $\sqrt{ }$ & - & 102 & 0.0562 & 0.0558 \\
\hline 6 & - & - & C & 8 & $\sqrt{ }$ & 4 & 0.0023 & 0.0023 \\
\hline 7 & $\sqrt{ }$ & - & - & D & $\sqrt{ }$ & 1 & 0.0006 & $8.3 \mathrm{E}-30$ \\
\hline 8 & - & $\sqrt{ }$ & - & - & $\sqrt{ }$ & 5 & 0.0026 & 0.0027 \\
\hline 9 & - & - & $\sqrt{ }$ & 要 & $\sqrt{ }$ & 142 & 0.0787 & 0.0791 \\
\hline 10 & - & $\sqrt{ }$ & $\sqrt{ }$ & - & $\sqrt{ }$ & 2 & 0.0012 & 0.0001 \\
\hline
\end{tabular}

